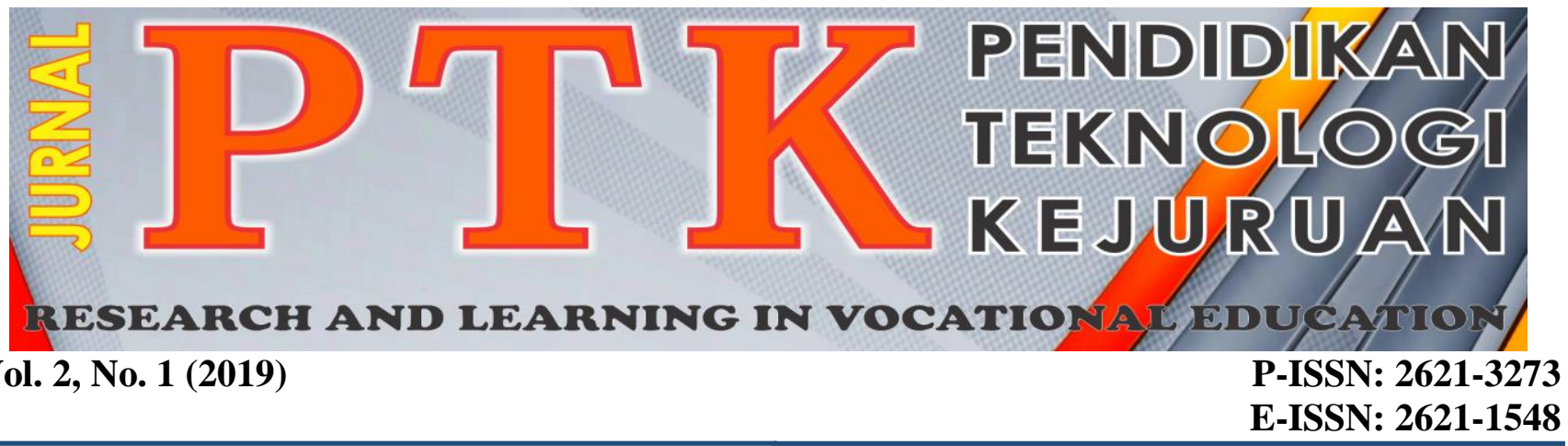

\title{
Analisis Faktor-Faktor Penerimaan Simoppeda di Bagian Administrasi Pembangunan Sekretariat Daerah Kabupaten Mukomuko
}

\author{
Daniel Agustian', Fahmi Rizal ${ }^{2}$, Dedy $\operatorname{Irfan}^{3}$ \\ ${ }^{1}$ Aparatur Sipil Negara Pemerintah Kabupaten Mukomuko, Provinsi Bengkulu \\ ${ }^{2,3}$ Pascasarjana Fakultas Teknik, Universitas Negeri Padang \\ *Corresponding author, e-mail: agustian.daniel@gmail.com ${ }^{1}$
}

\begin{abstract}
Abstrak - Simoppeda merupakan sistem informasi yang memberikan layanan informasi dan pelaporan terhadap pelaksanaan kegiatan pembangunan. Dalam pelaksanaannya, pemanfaatan Simoppeda masih belum optimal dan masih mengalami beberapa kendala. Penelitian ini dilakukan untuk menganalisis faktor-faktor penerimaan pengguna terhadap penerapan Simoppeda di Bagian Administrasi Pembangunan Sekretariat Daerah Kabupaten Mukomuko. Tujuan penelitian ini adalah untuk mengetahui hubungan antara persepsi kemudahan penggunaan, persepsi kegunaan, keyakinan diri, dan kondisi yang memfasilitasi dengan penerimaan Simoppeda. Penelitian dilaksanakan menggunakan metode penelitian korelasi dengan pendekatan kuantitatif. Penentuan sampel menggunakan teknik sampel jenuh. Uji validitas instrumen menggunakan teknik corrected item - total correlation, sedangkan uji reliabilitas menggunakan alpha cronbach. Teknik analisa data menggunakan statistik deskriptif dan statistik inferensial non parametrik Spearman Rank. Hasil penelitian menunjukkan bahwa terdapat hubungan yang kuat dan signifikan antara persepsi kemudahan penggunaan, persepsi kegunaan, keyakinan diri, dan kondisi yang memfasilitasi dengan penerimaan Simoppeda. Hasil ini dapat dijadikan pedoman dalam pengembangan Simoppeda agar memperhatikan faktor-faktor yang mendasari penerimaan Simoppeda.
\end{abstract}

Kata kunci : Penerimaan Simoppeda, Persepsi Kemudahan Penggunaan, Persepsi Kegunaan, Spearman

Abstract- Simoppeda is an information system that provides information services and reporting on the implementation of development activities. In its implementation, the use of Simoppeda is still not optimal and still facing several obstacles. This research is conducted to analyze the factors of user acceptance of Simoppeda implementation in the Development Administration Section of Regional Secretariat of Mukomuko Regency. The purpose of this study is to determine the relationship between perceived ease of use, perceived usefulness, selfefficacy, and facilitating conditions the acceptance of Simoppeda itself. The research employs correlational research method with quantitative approach. The determination of samples is by using saturated sample technique. Instrument validity test is by using corrected item - total correlation technique, while the reliability test used is alpha cronbach. The instrument is in the form of questionnaires. The data analysis technique used is descriptive statistics and nonparametric inferential statistics; Spearman Rank. The result showed that there is a strong and significant correlation between perceived ease of use, perceived usefulness, self-efficacy and facilitating conditions with the acceptance of Simoppeda. These results can be used as guidelines in the development of Simoppeda to pay attention to the factors that underlying the acceptance of Simoppeda.

Keywords: Acceptance of Simoppeda, Perceived Ease of Use, Perceived Usefulness, Spearman Rank 


\section{Pendahuluan}

Perkembangan teknologi informasi di Indonesia, membuat sebagian besar organisasi pemerintahan memanfaatkan teknologi informasi dalam mencapai transparasi, efisiensi dan efektifitas kerja dilingkungannya sehingga dalam organisasi tersebut terjadi perubahan dalam cara kerja dan proses bisnisnya. Pemanfaatan teknologi informasi dan komunikasi pada lingkungan pemerintahan atau dikenal dengan istilah electronic government (egovernment) telah dikembangkan dalam berbagai bentuk aplikasi sistem informasi. Salah satunya penggunaan aplikasi Simoppeda, yaitu Sistem Informasi Monitoring dan Pelaporan Pembangunan Daerah.

Simoppeda merupakan aplikasi berbasis internet yang digunakan untuk mempermudah dalam melakukan monitoring dan administrasi pelaporan kemajuan pelaksanaan kegiatan pembangunan di seluruh Organisasi Perangkat Daerah (OPD) dilingkungan Pemerintah Kabupaten Mukomuko. Namun pada penerapannya sampai saat ini, pemanfaatan Simoppeda masih belum optimal. Hal ini dapat dilihat pada webiste Simoppeda, masih ada data yang kosong disajikan pada beberapa menu pelaporan Simoppeda. Pada hal informasi data tersebut berguna bagi Kepala Daaerah dalam upaya identifikasi dan evaluasi permasalahan yang dihadapi oleh masing-masing OPD. Diduga hal ini terjadi karena masih adanya sebagian operator yang merasa kesulitan dalam penggunaan Simoppeda.

Kendala selanjutnya adalah masih ada sebagian operator yang merasa kebingungan dan ragu pada saat entry data beberapa form menu Simoppeda. Penyebabnya karena sebagian operator yang terbiasa melaksanakan pekerjaan secara manual merasa sulit beradaptasi dengan sistem yang terkomputerisasi. Sehingga membuat operator kurang yakin terhadap dirinya dalam menyelesaikan pekerjaannya tepat waktu. Diduga keyakinan diri operator terhadap kemampuannya menggunakan Simoppeda masih rendah.

Kondisi-kondisi yang memfasilitasi juga turut memegang andil terhadap penerimaan Simoppeda. Belum semua dari Tim Pelaksana Kegiatan Pengelola Website Simoppeda khususnya operator yang telah mendapatkan pelatihan penggunaan Simoppeda serta tidak adanya panduan atau pentunjuk penggunaan Simoppeda. Keterbatasan perangkat pendukung juga menjadi kendala dalam pemanfaatan Simoppeda. Jumlah perangkat hardware (komputer/laptop) yang digunakan untuk operasional Simoppeda sebanyak 10 unit yang tidak sebanding dengan jumlah pengelola website sebanyak 14 orang.

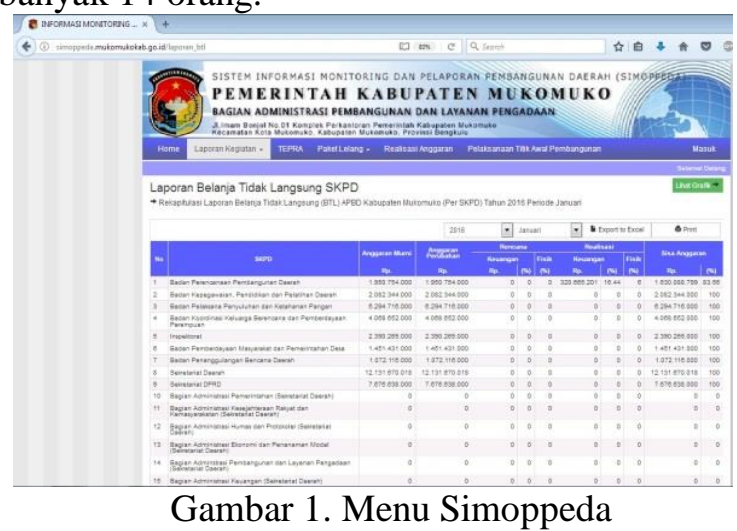

Berkaitan dengan kendala dan permasalahan di atas, perlu dilakukan penelitian untuk menganalisis faktor-faktor penerimaan Simoppeda dengan mengambil sudut pandang penerimaan pengguna terhadap penerapan Simoppeda. Dengan demikian dapat dilakukan evaluasi untuk peningkatan penerapan Simoppeda secara optimal bagi kemajuan pelaksanaan kegiatan pembangunan daerah Kabupaten Mukomuko. Tujuan yang hendak dicapai dalam penelitian ini adalah: (1) untuk mengetahui hubungan antara persepsi kemudahan penggunaan dengan penerimaan Simoppeda; (2) untuk mengetahui hubungan antara persepsi kegunaan dengan penerimaan Simoppeda; (3) untuk mengetahui hubungan antara keyakinan diri dengan penerimaan Simoppeda; (4) untuk mengetahui hubungan antara kondisi yang memfasilitasi dengan penerimaan Simoppeda.

\section{Studi Pustaka}

\section{A. Penerimaan Simoppeda}

Penerimaan pengguna terhadap sistem informasi merupakan unsur penting dalam penerapan suatu sistem informasi. Succi \& Walter menyatakan penerimaan terhadap sistem teknologi informasi dapat didefinisikan sebagai kemauan yang nampak di dalam kelompok pengguna untuk menerapkan sistem teknologi informasi tersebut dalam pekerjaannya. Jika pengguna tidak mau menerima sistem teknologi informasi yang baru, maka perubahan sistem tersebut menyebabkan tidak memberikan keuntungan yang banyak bagi organisasi [1].

[2] menyatakan, "Kesuksesan sebuah sistem informasi tidak hanya ditentukan oleh bagaimana sistem dapat memproses dan menghasilkan informasi dengan baik, tetapi juga bagaimana pengguna mau menerima dan menggunakannya, sehingga mampu mencapai tujuan organisasi". Penerimaan penggunaan dapat dijelaskan dari variasi penggunaan suatu sistem karena diyakini 
penggunaan suatu sistem yang berbasis teknologi informasi dapat mengembangkan kinerja individu atau kinerja organisasi [3].

\section{B. Persepsi Kemudahan Penggunaan}

Persepsi kemudahan penggunaan didefinisikan sebagai sejauh mana seseorang percaya bahwa menggunakan suatu teknologi akan bebas dari usaha ("is the extent to which a person believes that using a technology will be free of effort"). Dari definisinya, diketahui bahwa persepsi kemudahan penggunaan merupakan suatu kepercayaan tentang proses pengambilan keputusan. Jika seorang merasa percaya bahwa sistem informasi mudah digunakan maka dia akan menggunakannya, sebaliknya jika seorang merasa percaya bahwa sistem informasi tidak mudah digunakan maka dia tidak akan menggunakannya [4].

Goodwin \& Silver menyatakan, sistem yang lebih sering digunakan menunjukkan bahwa sistem tersebut lebih dikenal, lebih mudah dioperasikan dan lebih mudah digunakan oleh penggunanya [5]. Persepsi kemudahan penggunaan merupakan suatu ukuran dimana seseorang percaya bahwa teknologi tersebut dapat dengan mudah dipahami dan digunakan [6].

\section{Persepsi Kegunaan}

Persepsi kegunaan didefinisikan sebagai sejauh mana seseorang percaya bahwa menggunakan suatu teknologi akan meningkatkan kinerja pekerjaannya ("as the extent to which a person believes that using a technology will enhance her or his performance"). Dari definisinya tersebut, diketahui bahwa persepsi kegunaan juga merupakan suatu kepercayaan tentang proses pengambilan keputusan. Dengan demikian, jika seseorang merasa percaya bahwa sistem informasi berguna maka dia akan menggunakannya. Sebaliknya jika seseorang merasa percaya bahwa sistem informasi kurang berguna maka dia tidak akan menggunakannya [4]. Individu akan menggunakan teknologi informasi jika mengetahui manfaat positif atas penggunaannya [7].

\section{Keyakinan Diri}

Definisi keyakinan diri menurut [8] adalah keyakinan akan kemampuan individu untuk dapat mengorganisasi dan melaksanakan serangkaian tindakan yang dianggap perlu untuk mencapai suatu hasil yang diinginkan. Keyakinan diri menurut Ajzen adalah persepsi individual terhadap kemudahan atau kesulitan dalam melakukan perilaku atau keyakinan terhadap kemampuan sendiri untuk melakukannya [4]. Sedangkan menurut [4] keyakinan diri adalah kepercayaan-kepercayaan tentang kemampuan seseorang untuk melakukan suatu perilaku tertentu.

\section{E. Kondisi yang Memfasilitasi}

Menurut Triandis, kondisi yang memfasilitasi merupakan faktor-faktor obyektivitas yang ada di lingkungan kerja yang memudahkan pemakai dalam melakukan suatu pekerjaan dan pada konteks penggunaan personal komputer, penyediaan dukungan kepada pemakai-pemakai komputer personal mungkin satu tipe dari kondisi yang memfasilitasi yang dapat mempengaruhi pemanfaatan sistem [4]. Menurut [9] kondisi yang memfasilitasi didefinisikan sebagai sejauh mana seorang percaya bahwa infrastruktur organisasional dan kondisi yang memfasilitasi dapat mendukung sistem. Kondisi yang memfasilitasi didefinisikan sebagai sejauh mana seseorang percaya bahwa infrastruktur organisasional dan teknikal tersedia untuk mendukung sistem [4].

\section{F. SIMOPPEDA}

Simoppeda adalah serangkaian kegiatan perpaduan sumber daya manusia dengan sumber daya yang berbasis komputer untuk menyajikan informasi perkembangan pelaksanaan rencana pembangunan, mengidentifikasi serta mengantisipasi permasalahan yang timbul dan/atau akan timbul untuk dapat diambil tindakan sedini mungkin agar suatu program/kegiatan yang dilaksanakan tersebut sesuai dengan rencana yang ditetapkan [10].

Simoppeda merupakan aplikasi berbasis internet yang digunakan untuk mempermudah pemerintah daerah dan masyarakat dalam melakukan monitoring dan evaluasi kemajuan pelaksanaan kegiatan pembangunan di seluruh Organisasi Perangkat Daerah di lingkungan Pemerintah Kabupaten Mukomuko.

\section{G. Technology Acceptance Model (TAM)}

TAM merupakan salah satu model evaluasi untuk mencari tahu faktor-faktor yang menyebabkan orang untuk menerima atau menolak teknologi informasi. TAM beragumentasi bahwa penerimaan individual terhadap sistem teknologi informasi ditentukan oleh persepsi kegunaan dan persepsi kemudahan penggunaan [4]. TAM merupakan model yang dianggap mampu untuk mengidentifikasi, memahami dan menjelaskan faktor-faktor yang mempengaruhi diterimanya penggunaan teknologi [11]. 


\section{METODE}

Penelitian ini mengunakan pendekatan kuantitatif dengan metode penelitian korelasional, dimana metode ini bertujuan untuk mengetahui tingkat hubungan antara dua variabel atau lebih, tanpa melakukan perubahan, tambahan atau manipulasi terhadap data yang sudah ada [12]. Variabel penelitian terdiri dari variabel bebas, yaitu persepsi kemudahan penggunaan, persepsi kegunaan, keyakinan diri dan kondisi yang memfasilitasi serta variabel terikat, yaitu penerimaan Simoppeda.

Penelitian dilakukan di Bagian Administrasi Pembangunan Sekretariat Daerah Kabupaten Mukomuko pada bulan Maret 2018. Populasi dalam penelitian ini adalah pegawai yang menggunakan Simoppeda di Sekretariat Daerah Kabupaten Mukomuko, yaitu Tim Pelaksana Kegiatan Pengelola Website Simoppeda yang berjumlah 14 orang. Teknik pengambilan sampel menggunakan teknik sampling jenuh, yaitu teknik penentuan jumlah sampel bila semua anggota populasi digunakan sebagai sampel jika jumlah populasi relatif kecil, kurang dari 30 orang [13].

Penelitian ini menggunakan variabel independen yaitu persepsi kemudahan penggunaan, persepsi kegunaan, keyakinan diri, dan kondisi yang memfasilitasi. Sedangkan variabel dependennya adalah penerimaan Simoppeda. Pengumpulan data dilakukan dengan cara menyebarkan kuesioner (angket) dengan skala pengukuran instrumen menggunakan skala Likert. Sebelum melakukan penelitian, peneliti meminta pendapat ahli terhadap kelayakan isi instrumen untuk diperiksa dan dievaluasi menggunakan kuesioner dari [14]. Kemudian melakukan uji coba instrumen untuk mengetahui validitas dan reliabilitas instrumen.

Uji validitas menggunakan teknik Corrected Item - Total Correlation, yaitu mengkorelasikan masing-masing skor item pertanyaan dengan skor total dan melakukan koreksi terhadap nilai koefisien korelasi yang overestimasi. Sedangkan uji reliabilitas hanya dilakukan pada pertanyaan yang valid saja dengan menggunakan teknik Cronbach's Alpha.

Teknik analisis data dalam penelitian ini menggunakan statistik deskriptif dengan penghitungan derajat pencapaian [15]. Sedangkan untuk menjawab hipotesis, digunakan statistik inferensial non parametrik Spearman Rank.

\section{HASIL DAN PEMBAHASAN}

\section{A. Analisis Statistik Deskriptif}

Hasil penghitungan derajat pencapaian yang telah dilakukan, tingkat penerimaan Simoppeda masuk dalam kategori cukup dengan derajat pencapaian
$68,21 \%$. Sedangkan variabel-variabel yang mendasari penerimaan Simoppeda juga memiliki tingkat pencapaian pada kategori cukup. Rangkuman hasil penghitungan derajat pencapaian dapat dilihat pada Tabel 1.

Tabel 1. Rangkuman Hasil Penghitungan Derajat Pencapaian

\begin{tabular}{lcc}
\hline \multicolumn{1}{c}{ Variabel } & $\begin{array}{c}\text { Derajat } \\
\text { Pencapaian }\end{array}$ & Interpretasi \\
\hline $\begin{array}{l}\text { Persepsi } \\
\text { Kemudahan } \\
\text { Penggunaan }\end{array}$ & $70,71 \%$ & Cukup \\
\hline $\begin{array}{l}\text { Persepsi } \\
\text { Kegunaan }\end{array}$ & $74,69 \%$ & Cukup \\
\hline Keyakinan Diri & $73,81 \%$ & Cukup \\
\hline $\begin{array}{l}\text { Kondisi yang } \\
\text { Memfasilitasi }\end{array}$ & $76,33 \%$ & Cukup \\
\hline $\begin{array}{l}\text { Penerimaan } \\
\text { Simoppeda }\end{array}$ & $68,21 \%$ & Cukup \\
\hline
\end{tabular}

Tingkat capaian penerimaan Simoppeda ini bukanlah hal yang memuaskan dan belum sesuai harapan, mengingat pentingnya Simoppeda dalam memberikan layanan informasi pembangunan daerah kepada publik. Kedepannya perlu menjadi perhatian bagi Stakeholder dan pihak pengembang sistem selanjutnya untuk memperhatikan faktor-faktor yang mendasari penerimaan Simoppeda

\section{B. Analisis Statistik Inferensial Non Parametrik Spearman Rank}

Hipotesis yang telah dirumuskan diuji menggunakan teknik korelasi Spearman Rank. Penelitian ini mendapatkan temuan bahwa penerimaan Simoppeda memiliki hubungan yang kuat dan signifikan dengan persepsi kemudahan penggunaan, persepsi kegunaan, keyakinan diri, dan kondisi yang memfasilitasi. Tingkat hubungan masing-masing variabel ditunjukkan dengan melihat nilai koefisien korelasi pada analisis Spearman Rank pada Tabel 2.

1. Hubungan antara Persepsi Kemudahan Penggunaan dengan Penerimaan Simoppeda

Hasil analisis data pada Tabel 2 menunjukkan koefisien korelasi antara persepsi kemudahan penggunaan dengan penerimaan Simoppeda sebesar 0,625 dengan tingkat signifikansi 0,008 . Hal ini berarti, terdapat hubungan yang kuat dan signifikan antara persepsi kemudahan penggunaan dengan penerimaan Simoppeda. Semakin pengguna merasakan kemudahan dalam menggunakan Simoppeda, maka Simoppeda akan semakin diterima. 
Tabel 2. Hasil Analisis Korelasi Spearman Rank

\begin{tabular}{|c|c|c|c|c|c|c|}
\hline No. & Hipotesis & $\begin{array}{c}\rho \\
\text { hitung }\end{array}$ & $\begin{array}{l}\text { o tabel } \\
(95 \%)\end{array}$ & Sig. & KD & Keterangan \\
\hline 1. & $\begin{array}{l}\text { Terdapat hubungan yang signifikan antara } \\
\text { persepsi kemudahan penggunaan dengan } \\
\text { penerimaan Simoppeda }\end{array}$ & 0,625 & 0,544 & 0,008 & $39,06 \%$ & $\begin{array}{l}\text { Diterima } \\
(\rho \text { hitung }>\rho \\
\text { tabel) }\end{array}$ \\
\hline 2. & $\begin{array}{l}\text { Terdapat hubungan yang signifikan antara } \\
\text { persepsi kegunaan dengan penerimaan } \\
\text { Simoppeda }\end{array}$ & 0,746 & 0,544 & 0,001 & $55,65 \%$ & $\begin{array}{l}\text { Diterima } \\
(\rho \text { hitung }>\rho \\
\text { tabel })\end{array}$ \\
\hline 3. & $\begin{array}{l}\text { Terdapat hubungan yang signifikan antara } \\
\text { keyakinan diri dengan penerimaan Simoppeda }\end{array}$ & 0,669 & 0,544 & 0,004 & $44,76 \%$ & $\begin{array}{l}\text { Diterima } \\
(\rho \text { hitung }>\rho \\
\text { tabel) }\end{array}$ \\
\hline 4. & $\begin{array}{l}\text { Terdapat hubungan yang signifikan antara } \\
\text { kondisi yang memfasilitasi dengan } \\
\text { penerimaan Simoppeda }\end{array}$ & 0,649 & 0,544 & 0,006 & $42,12 \%$ & $\begin{array}{l}\text { Diterima } \\
(\rho \text { hitung }>\rho \\
\text { tabel) }\end{array}$ \\
\hline
\end{tabular}

Hasil pengujian ini konsisten dengan penelitian [16] bahwa variabel persepsi kemudahan penggunaan juga memiliki hubungan yang signifikan terhadap penerimaan teknologi. Hal ini juga didukung oleh penelitian [17] yang menemukan persepsi kemudahan penggunaan berpengaruh positif terhadap penerimaan penggunaan sistem informasi.

2. Hubungan antara Persepsi Kegunaan dengan Penerimaan Simoppeda

Analisis data pada Tabel 2 menunjukkan koefisien korelasi antara persepsi kegunaan dengan penerimaan Simoppeda sebesar 0,746 dengan tingkat signifikansi 0,001 . Hal ini menjelaskan bahwa terdapat hubungan yang kuat dan signifikan antara persepsi kegunaan dengan penerimaan Simoppeda. Semakin pengguna merasakan kegunaan Simoppeda dalam pekerjaannya, maka semakin tinggi penerimaan pengguna terhadap Simoppeda.

Hasil pengujian ini konsisten dengan penelitian [3] yang menemukan adanya hubungan positif antara persepsi kegunaan dengan penggunaan sistem informasi. Sejalan dengan penelitian [16] bahwa variabel persepsi kegunaan memiliki hubungan yang signifikan terhadap penerimaan teknologi. Hal ini juga didukung oleh penelitian [1] yang menyatakan persepsi kegunaan berpengaruuh signifikan terhadap penggunaan teknologi.

3. Hubungan antara Keyakinan Diri dengan Penerimaan Simoppeda

Analisis data pada Tabel 2 menunjukkan koefisien korelasi antara keyakinan diri dengan penerimaan Simoppeda sebesar 0,669 dengan tingkat signifikansi 0,004 . Hal ini menjelaskan bahwa terdapat hubungan yang kuat dan signifikan antara keyakinan diri dengan penerimaan Simoppeda. Semakin tinggi keyakinan diri pengguna, maka akan semakin tinggi penerimaan pengguna terhadap Simoppeda.
Hasil pengujian ini konsisten dengan penelitian Gist et.al dan Burckhardt \& Brass yang menyatakan bahwa faktor keyakinan diri berhubungan secara signifikan dengan persepsi para pengguna tentang teknologi tersebut [4]. Penelitian tersebut juga didukung oleh penelitian [18] yang menyimpulkan bahwa variabel keyakinan diri berpengaruh signifikan terhadap keinginan menggunakan teknologi.

4. Hubungan antara Kondisi Yang Memfasilitasi dengan Penerimaan Simoppeda

Analisis data pada Tabel 2 menunjukkan koefisien korelasi antara kondisi yang memfasilitasi dengan penerimaan Simoppeda sebesar 0,649 dengan tingkat signifikansi 0,006. Hal ini menjelaskan bahwa terdapat hubungan yang kuat dan signifikan antara kondisi yang memfasilitasi dengan penerimaan Simoppeda. Semakin baik kondisi yang memfasilitasi penggunaan Simoppeda, maka akan semakin baik penerimaan pengguna terhadap Simoppeda.

Hasil pengujian ini konsisten dengan penelitian [19] yang menemukan korelasi positif antara kondisi yang memfasilitasi dengan penggunaan sistem. Hal ini juga didukung penelitian [20] yang menunjukan hasil adanya hubungan yang signifikan antara fasilitas yang diberikan organisasi dengan penerimaan teknologi informasi. Sejalan juga dengan penelitian [9] bahwa kondisi yang memfasilitasi pengguna mempunyai pengaruh pada perilaku penggunaan teknologi informasi pada karyawan.

\section{KESIMPULAN}

Berdasarkan hasil penelitian dan pembahasan yang telah dikemukan pada bagian sebelumnya, terdapat hubungan yang kuat dan signifikan antara persepsi kemudahan penggunaan, persepsi kegunaan, keyakinan diri, kondisi yang memfasilitasi dengan penerimaan Simoppeda. 
Sehingga disarankan kepada Pemerintah Kabupaten Mukomuko dalam pengembangan Simoppeda sebaiknya memperhatikan faktor-faktor pengguna yang mendasari penerimaan Simoppeda (persepsi kemudahan penggunaan, persepsi kegunaan, keyakinan diri, kondisi yang memfasilitasi) untuk keberhasilan penerimaan Simoppeda secara optimal, seperti menyediakan panduan penggunaan dan teknisi, pelatihan atau bimbingan teknis bagi Tim Pelaksana Kegiatan Pengelola Website Simoppeda, serta meningkatkan sarana dan prasarana penunjang Simoppeda.

\section{DAFTAR PUSTAKa}

[1] Pikkarainen, T, Pikkarainen, K, Karjaluoto, H, \& Pahnila, S. "Consumer Acceptance of Online Banking: An Extension of The Technology Acceptance Model". Internet Research, Volume 14 Number 3 pp. 224-235, 2004.

[2] Fran Sayekti \& Pulasna Putarta. "Penerapan Technology Acceptance Model (TAM) Dalam Pengujian Model Penerimaan Sistem Informasi Keuangan Daerah”. Jurnal Manajemen Teori dan Terapan. Nomor 3, Desember 2016.

[3] Iqbaria M. "An Examination of the Factors Contributing to Micro Computer Technology Acceptance". Journal of Information System. Elsiever Science. USA, 1994.

[4] Jogiyanto. Sistem Informasi Keprilakuan. Yogyakarta: Andi Offset, 2007.

[5] Adam Denis, Nelson Ryan, Todd Peter. "Perceived Usefulness, Ease of Use and Usage of Information Technology: A Replication". Management Information System Quaeterly : Vol. 16, No. 2 (Jun., 1992), pp. 227-247.

[6] Arief Wibowo. "Kajian tentang Perilaku Pengguna Sistem Informasi dengan Pendekatan Technology Acceptance Model (TAM)". Proceeding Book of Konferensi Nasional Sistem Informasi, 14-15 Januari, 2008.

[7] Thompson, R. L, Higgins, CA and Howell, JM. "Personal Computing: Toward a Conceptual Model of Utilization". Management Information System Quaeterly, 15(1): 125-143, 1991.

[8] Bandura. Self-Efficacy, The Exercise of Control. New York: W.H Freeman and Company, 1997.

[9] Venkatesh, V., Morris, M. G., Davis, G. B., \& Davis, F. D. "User Acceptance of Information Technology: Toward a Unified View". Management Information System Quaeterly, 27, 425-478, 2003.

[10] Peraturan Pemerintah Nomor 39 Tahun 2006 tentang Tata Cara Pengendalian dan Evaluasi Pelaksanaan Rencana Pembangunan.
[11] Brigita Angga Wulan, Bambang Soedijono W.A, Henderi. "Evaluasi Penerimaan Bio Sistem Online Menggunakan Pendekatan Technology Acceptance Model (TAM)". Jurnal Teknologi Informasi. Vol. XII Nomor 34 Maret 2017. ISSN: 1907-2430.

[12] Arikunto Suharsimi. Prosedur Penelitian: Suatu Pendekatan Praktik. Jakarta: Rineka Cipta, 2010.

[13] Sugiyono. Statika untuk Penelitian. Bandung: Alfabeta, 2010.

[14] Gendon Barus. "Pengembangan Instrumen Assesmen Kebutuhan Perkembangan untuk Penyusunan Kurikulum dan Evaluasi Program BK". Jurnal Penelitian dan Evaluasi Pendidikan. Vol. 15, No. 1, 2011.

[15] Syahron Lubis. Metode Penelitian Pendidikan. Padang: UNP Press, 2011.

[16] Lederer, A.L, Maupin, D.J, Sena, M.P, \& Zhuang, Y. "The Technology Acceptance Model and the World Wide Web". Decision Support System. 29: 269-282, 2000.

[17] Venkatesh, V \& Davis, F.D. "A Theoretical Extension of the Technology Acceptance Model: Four Longitudinal Field Studies". Management Science. Vol. 46, No. 2 (Feb., 2000), pp. 186-204, 2000.

[18] Vijayasarathy, L.R. "Predicting Consumer Intentions to Use Online Shopping: The Case for an Augmented Technology Acceptance Model". Information \& Management Journal. 41:747-762, 2004.

[19] Robey, D. User Attitudes and Management Information System Use. The Academy of Management Journal. 22(3): 527-538, 1979.

[20] Schillewaert, Niels, Michael Ahearne, Rund Frambach, And Rudy K. Moenaert. "The Acceptance of Information Technology In The Sales Force". Journal of Marketing, December 11, Institute for The Study of Business Markets (ISBM), Pennsylvania, 2000.

\section{Biodata Penulis}

Daniel Agustian, lahir di Padang, 16 Agustus 1983. Menyelesaikan Diploma IV Pekerjaan Sosial di STKS Bandung tahun 2013. Tahun 2018 memperoleh gelar Magister Chief Information Officer pada program studi Pendidikan Teknologi Kejuruan Pascasarjana Fakultas Teknik UNP dengan bidang konsentrasi Chief Information Officer. Penulis saat ini bekerja sebagai Aparatur Sipil Negara pada Pemerintah Kabupaten Mukomuko, Provinsi Bengkulu 